\title{
NEWLY QUALIFIED FOREIGN LANGUAGE TEACHERS' ADAPTATION IN PROFESSION: CHALLENGES, PROBLEMS, FIRST ACHIEVEMENTS AND FURTHER PROSPECTS
}

\author{
Oleh Komar, Anhelina Kolisnichenko, Svitlana Derkach, Tetiana Kapeliushna \\ Pavlo Tychyna Uman State Pedagogical University \\ a.kolisnichenko@udpu.edu.ua
}

\begin{abstract}
Ukrainian reforms in higher education and participation of universities in different international programmes open new perspectives for quality assurance rising. This study focuses on the foreign language teachers' professional readiness during their initial period of work and provides an important opportunity to advance the understanding of the main changes in education and their influence on newly qualified FL teachers' adaptation in the profession. The concept of "foreign language teachers' training" is studied in the context of the pedagogical field, determining the personality of the future teacher, professional suitability; content of education, application. These prerequisites of newly qualified FL teachers are defined as reasonable and desired for further professional development. As a qualitatively oriented study, the purpose of the suggested investigation was to find out newly qualified teachers' experience, serious challenges, benefits and, moreover, to explore best practices in order to support newly qualified teachers in their initial career. A variety of qualitative and quantitative tools of survey for collecting data was applied for measurement as a basic study design. The main study findings outline perplexing problems for the FL teachers to solve: paperwork, time management, low salaries and affective filters. Another important finding was that newly qualified teachers need a mentor who can give a methodological support. The results show a significant importance in "New generation School Teacher" programme further implementation in the FL teachers training course.
\end{abstract}

Keywords: newly qualified teachers; foreign language (FL) teachers; university training courses; professional activity; professional adaptation.

\section{Introduction}

European countries strive to meet higher social and economic challenges and improve their education systems. The main attention is paid to teachers' training, as they are considered the most important resource in the learning process and agents of change who need constant professional development. The quality of teachers' education depends on their desire to work as teachers and the students' access to higher education (Kearney, 2013; Darling-Hammond \& Baratz-Snowden, 2007; England, 2019; Knight, Tait \& Yorke, 2006; Adendorff et al., 2010).

Ukraine approved its European choice and foreign policy vector, commitment to European integration and globalisation, membership in the European Higher Education Area, European Research Area, other international institutions, partnerships and cooperation. Ukraine recognises higher education as a resource of social transformation. In this context, the English language is treated as a key competence for economic integration and globalisation, an instrument of international communication, a means of joining the European educational, scientific and professional space, conditions of effective integration and economic growth. (Conceptual Principles Project, 2019).

Tican \& Deniz (2019) points out that the skills needed by people in the 21 st century in terms of professional life, citizenship and self-actualisation are highly different from the ones needed in the 20th century. (p. 181). Recent transformations in Ukrainian higher education have created the field for new research. Taken together new changes that have appeared in the teachers' training programmes at Ukrainian universities and reforms in primary and secondary education the necessity to study newly qualified teachers (NQTs) experience in work adaptation have appeared. The New Ukrainian School reform created new conditions, challenges and opportunities for newly qualified teachers. One more reason to start this research is the scientific interest in the result of the project "New generation school teachers" the first graduates of which started their work in 2019-2020 (Bevs et al., 2020).

The novelty of this study is to receive the most considerable findings of the research concerning newly qualified FL teachers' professional activity during initial years at school and to identify main challenges for newly qualified teachers, problems and achievements in teachers' education.

The aim of the paper is to study new challenges, problems that newly qualified FL teachers experience during their initial adaptation in their profession. According to the aim, we are striving to reveal the answers

(C) Oleh Komar, Anhelina Kolisnichenko, Svitlana Derkach, Tetiana Kapeliushna. 2021. Published by Igor Sikorsky Kyiv Polytechnic Institute. This is an Open Access article distributed under the terms of the licence CC BY 4.0 
to the directly related research questions: what problems do newly qualified FL teachers experience at the beginning of their careers and what supportive and additional measures do they demand.

\section{Literature review}

The issue of standardisation of education and FL teachers' formal training in different countries has been the subject of research developed by many Ukrainian scholars: Biletska (2014), Bondaruk (2018), Hryniuk (2015), Zabolotna (2014), Komar (2017), Protsko (2015) and others, who partially mention the standards and requirements for formal education in some countries. Seeing the importance of compliance with international requirements for the professional formal teacher education quality, the need for a more detailed study of this issue is outlined.

The main reasons for the growing interest are the fact and reality that the formal teacher education more or less requires systems for gradual introduction and additional support for newly qualified FL teachers during the initial years of work; the possibilities and demand to promote newly qualified FL teachers' professional development; the fact that many newly qualified FL teachers leave the teaching profession early; the risk of shortage of teachers; that teachers often are an overrepresented group regarding absence due to sickness, or a mistrust towards initial teacher education.

The above aspects of newly qualified teachers have been investigated and under grounded discussions in numerous research because the first years of teaching for novice prove to be challenging and time-consuming (Høigaard, Giske \& Sundsli, 2012; He \& Cooper, 2011; Sunde \& Ulvik, 2014).

In this context, it is logical that newly qualified teachers' professional development and their workplace appear frequently in educational documents, in various studies, in order to develop systems prospectively to support and motivate professional development. Teachers need different types of professional development at different times in their careers (Livingston, 2014).

The term "newly qualified teacher" has been used for different durations of the teaching process of teachers who graduate from university or college. In various sources, the exact number of years for a beginning teacher differs from three to five. Also, we find different concepts in place of the NQT such as novice teachers, beginning teachers and new teachers (Fransson \& Gustafsson, 2008).

Newly qualified teachers' needs have been explored in the study of Vilhelmiina Harju and Hannele Niemi. They investigated the need for professional development support among newly qualified teachers to determine what their professional learning needs are and how these needs differ among teachers from four different countries: Finland, the United Kingdom (England), Portugal and Belgium (Flanders). The results of this study cannot be generalised, they provide an important overview of new teachers' learning needs that should be taken into account when planning and organising support for them (Harju \& Niemi, 2016).

Through the viewpoint of developments, according to Results of the All-Ukrainian monitoring survey of teaching and training among directors and teachers of comprehensive educational institutions: Ukrainian teachers and the learning environment (Shchudlo, Zabolotna \& Lisova, 2018), we find out, on the one hand, that the most critical professional development needs for Ukrainian teachers are to improve the skills of information and communication technologies (ICT) for training and mastering new technologies in the workplace. On the other hand, it is stated in this report that there are plenty of obstacles in professional development of Ukrainian teachers. This is the implementation of professional development measures during teachers' working hours and the lack of rewards for participation in these events.

According to Olena Trynus (2017), solving the problems of becoming a newly qualified teacher is rather complicated due to the existence of a number of negative factors, worked out by:

- the uncertainty of the young teacher's status in Ukraine;

- the lack of government support for this category of pedagogical workers;

- the low adeptness of the teacher's profession;

- insufficient practical training of the future teacher during his studies in higher education with a preference to theoretical professional training;

- unsatisfactory level of young teachers' knowledge on the essence of their professional activity;

- lack of students' motivational readiness for pedagogical activities (the level of employment of graduates of pedagogical specialities in Ukraine is only 80-85\%);

- the specifics of pedagogical activity (p. 15-19).

A recent study by Koliada and Kolisnichenko (2020) involved students' evaluation of their training programme. The purpose of the research was to examine how future foreign language teachers who are getting formal university education, assess the quality of their training programme and its relevance to their professional needs. The results of the survey cause out interest as they reveal the prerequisites for 
professional adaptation (Koliada \& Kolisnichenko, 2020). Obviously, a newly qualified teacher's workplace and development are placed under a spotlight and have a range of problems, challenges to solve reasonably.

\section{Methods}

Research Design. Taking into account relevant resources and theory on this issue, we made up our mind that a survey is considered to be quite a reliable and effective scientific method for the grounded research; therefore, it may provide our study with sustainable data and significant findings in order to make this investigation worthwhile. To gain as much understanding of the issue under analysis as possible, it was decided to try and see the problems from different perspectives and challenges of newly qualified teachers (with working experience of 1-3 years) in Ukrainian secondary schools. For conducting a comprehensive study on defined issue we used a combination of quantitative (questionnaire) and qualitative (analysis of respondents' answers in the survey) means of data collection (see Fig.1).

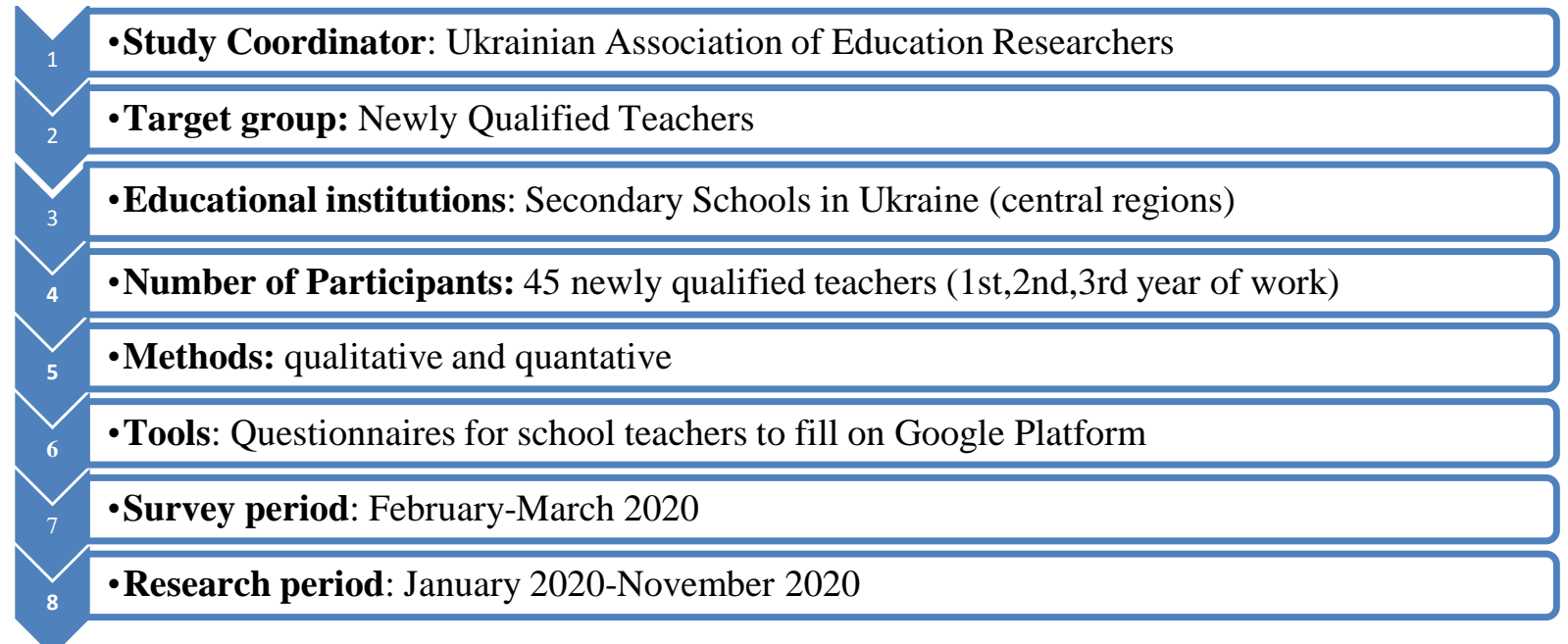

Figure 1. Characteristics of the monitoring design survey of newly qualified teachers in Ukraine (2020)

\section{Participants}

Altogether data from 45 participants were included in the analyses of the study. In fact, throughout Ukraine, a great number of teachers were asked and slightly convinced to answer the survey questions and as a result, it was a fruitful line of a research to obtain data from 6 Ukrainian universities who were recruited for this study and in this regard, brought a global perspective for the paper. Exactly, of all respondents cohort, 93 $\%$ (42 participants) were female and $7 \%$ (3 participants) - male. Primarily, care was taken in the selection and design of materials to ensure that they were appropriate in terms of the age of the participants. The respondents have just begun their teacher careers, having been working for the first year $(51,1 \%)$, the second year $(22,2 \%)$, the third year $(26,7 \%)$. The larger number of first-year-work teachers gives the opportunity for better analysis and outlining the main features of career adaptation. It was also important to account for the different factors that could affect participants. Biographical information was not taken for all participants as our focus was on what problems, challenges, benefits potential teachers faced in their school practice rather than making comparisons between the responses of different groups of teachers. This reflects the exploratory nature of the study.

Importantly, it was necessary to involve as many representatives of newly qualified teachers from different geographical areas of Ukraine as possible so that to obtain real and effective results. The potential drawback is that it is impossible to define the exact percentage of geographical involvement, since not every respondent filled in the lines of the questions with the detailed information about their place of getting the education and work. Remarkably, it was enough to underscore that there were representatives from western, eastern and central parts of Ukraine.

\section{Instruments and procedure}

While preparing for the research we started working with the resources that are mostly connected with the theme of the research. It was necessary to identify the main aspects of the paper. Overwhelming efforts were put to plan, outline each section, work out qualitative methods that helped to underscore and reveal effective findings of this research. Practically, the most crucial in this phase was fact-finding process to 
refine the ideas about the general focus area, to properly select necessary questions for gaining optimal results and prepare a more systematic investigation at all.

In fact, this investigation is a collaborative work planned carefully, analysed systematically and done by a group of professors of Faculty of Foreign Languages, Department of English Language and Methods of Teaching at Pavlo Tychyna Uman State Pedagogical University, Ukraine. According to study plan, coauthors of this research gathered periodically at every stage of study process. Since January 2020, each contributor has been sharing ideas or materials on the issue, and what is more, monthly group discussions have been organised to consider all research points and direct the further research actions.

Thus, it has been discovered that a research design should contain detailed information about Research topic, Objectives, Concepts and their operational definition, Variables, Hypothesis, Method of data collection $\&$ method of the data process, Analysis and interpretation, Time dimension of study and approximate expenditure involve (Ram, 2010).

\section{Data Analysis}

Initially, the data for the study was collected due to a digital version of questionnaire which was sent to newly qualified teachers in February 2020. Precisely, the Google Forms questionnaire was designed and suggested for participants; and it is worth admitting that such kind of electronic survey proved to be timeconsuming, reliable, feasible, rapid and economic way to generalise findings. Consequently, it was spread among pedagogical university graduates by using their connection with universities where they got formal education and uploaded in Viber messenger and Social networks (Facebook, Instagram). In this study, the questionnaires consisted of 20 questions in which newly qualified teachers could select their answers and share their personal opinions. Overall, it took 2 months to receive and collect survey's responses from participants. Indicating the time frame initial studies were carried out using the conditions described above over a period of 2020-2021. The study was split into three cycles to allow for time for reflection and to make any changes necessary.

\section{Ethical Issues}

The project was conducted with regard to the Ethical Guidelines for Educational Research (BERA 2011) and reviewed by the Board of Department of English Language and Methods of Teaching, Faculty of Foreign Languages at Pavlo Tychyna Uman State Pedagogical University in order to permit to conduct the research. Following ethics, the participation in the project was mainly voluntary, though convincing strategies were used either. Participants were informed about the nature of the research and how the research findings would be used before they took the questionnaire. Primarily, it was anonymous. The principals were asked to forward the questionnaire to the potential new teachers in their schools. That is to say, the participants in our research were fully protected and had confidence that we would not misuse the questionnaires, we explained the research to them thoroughly, answered their questions.

Although each of these methodology instruments can potentially contribute to fulfilling the overall aim of the study, the significance of each is greatly valuable. The data were generated in a way that is consistent with accepted practice in this field of study. With the completion of baseline steps above, we are ready now to highlight the main and sustainable findings of the study.

\section{Results}

The aspects, we were interested in, concerned the methodology course that participants studied at their universities. The Methodology course is one of the majors in the university curriculum for ESL teachers training and greatly influences teacher development. There are two methodology courses in Ukrainian universities curriculums:

- Traditional which includes three credits ECTS (90 hours) with theoretical lectures, some seminars and is delivered one term. This course is rather old and widely spread among pedagogical universities. The language of teaching is Ukrainian.

-Pre-service English Teacher Training Programme consists of twenty-two credits ECTS (660 hours) with practical sessions teaching and six-term duration. This course was suggested and supported by the British Council and it is greatly innovative with the focus on competence formation and use. But only 13 universities in Ukraine took part in creating and implementing this course. The language of teaching is English.

In this paper, we are also aimed to investigate if there may be any differences in respondents' answers

focusing on methodology course training programme. The following key findings emerged from the analyses. According to survey data, apparently $62,2 \%$ of respondents studied the traditional methodology 
course; 31,1\% had Pre-service English Teacher Training Programme as the methodology training; there are more responses among which: both programmes - 2,2\%;2,2\% - did not finish the programme (but we can add it to the pre-service programme according to its duration) 2,2 $\%$ - were not sure. Figure 2 below illustrates the prevailing of the traditional Methodology course.

What methodology course did you study at university?

45 responses

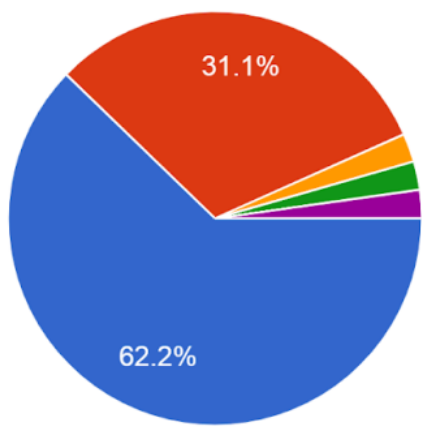

Traditional (1 or 2 terms)

New generation school teacher course (6 terms)

5 terms

Traditional and new generation school teacher course

Difficult to answer

Figure 2. Survey diagram with the data on the Methodology courses types

Respondents were asked to indicate whether they were ready for teaching English at schools after graduation from the university. It is even more impressive to see that this indicator can show the level of self-confidence that can greatly influence adaptation to work conditions and challenges. However, it is important to note that the results of these responses can suggest that majority of respondents consider themselves ready enough for their professional activity but on different levels. They were suggested to evaluate their basic formal education from 1 (Poor) to 5 (Excellent). The results when compared demonstrate that participants, unexpectedly, started with level ' 3 ' ' $(24,4 \%)$, the highest rate, fortunately, is ' 4 ' $(55,6 \%)$ and the number of completely ready newly qualified FL teachers, who assessed their level with ' 5 ' is (20\%). The results are presented in figure 3 .
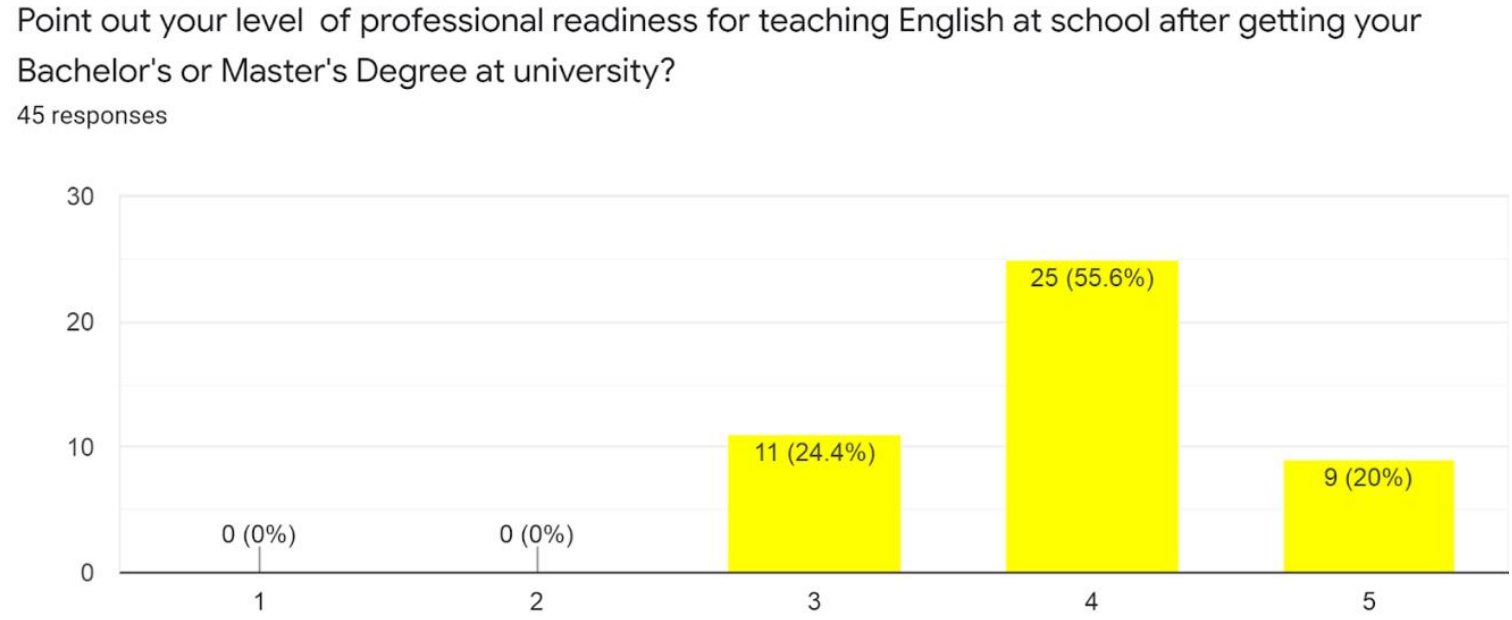

Figure 3. Survey diagram reflecting the respondents' professional readiness for teaching English

Moreover, it is also important to consider the effectiveness of the ESL teacher training programme for the level of professional readiness for teaching English at school. To find the figures we used the data of the question about the methodology course training and the formula: $\mathrm{C} 1$ : $\mathrm{C} 2 \times 100$, where $\mathrm{C} 1$ is the number of respondents who evaluated their professional readiness and $\mathrm{C} 2$ is the general quantity of the definite Methodology course cohort. The results of the correlational analysis are demonstrated in Table 1.

The most remarkable result to emerge from the data is that the traditional methodology learners' lower level of professional readiness indicates the importance of Pre-service English Teacher Training Programme application in university curriculums.

Generally speaking, the collected data have further strengthened our conviction that formal education is definitely obligatory and essential for starting a teaching career, though for high values of newly qualified teachers additional support is absolutely necessary, and of course, more individual, than while studying. It is 
crucial to note that they can find it by being a member of the professional organisations or educational hubs, so the next section of the questionnaire required respondents to give information about the support they have got. The analysis of the age range of learners whom respondents teach showed that more teachers work with junior students of the middle school $(26,7 \%)$ and young learners $(17,8 \%)$ all the rest work with learners of different age groups. Interestingly, those respondents who work with middle school students more often ignore additional activities $(58,3 \%)$ than others but those who work with young learners need more help during their professional adaptation and are more active in participating in seminars or workshops.

Table 1. Newly qualified FL teachers' professional readiness

\begin{tabular}{|c|c|c|}
\hline $\begin{array}{c}\text { Level of professional readiness } \\
\text { from 1 to 5 }\end{array}$ & $\begin{array}{c}\text { Traditional } \\
\text { Methodology course (\%) }\end{array}$ & $\begin{array}{c}\text { Pre-service English } \\
\text { Teacher Training Programme (\%) }\end{array}$ \\
\hline 1 (poor) & 0 & 0 \\
\hline 2 (not bad) & 0 & 0 \\
\hline 3 (satisfactory) & 35,7 & 6,2 \\
\hline 4 (good) & 46,7 & 75 \\
\hline 5 (excellent) & 17,9 & 18,8 \\
\hline
\end{tabular}

Strikingly, the overall response to this question was poor: unfortunately, the overwhelming majority of respondents do not join any professional or educational organisations $(93,3 \%)$ while only 3 teachers $(6,7 \%)$ mentioned about membership in some groups: "Excellence", "English Teachers". As a result, newly qualified teachers are searching for other helpful resources like seminars, webinars, workshops etc. The majority of those who responded to this question elicited that they anticipated such types of activities $(77,8 \%)$ but some of them consider that they were not helpful $(6,7 \%)$. The rest of the respondents $22,2 \%$ did not take part in any additional activities, the overall result is shown in figure 4.

Do you participate in seminars, webinars, workshops, conferences? If yes, tick events.

45 responses
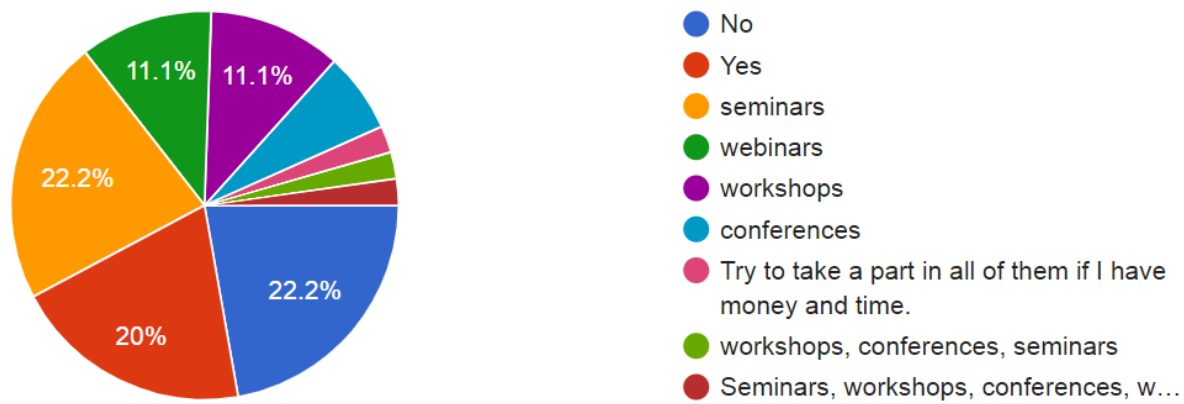

Figure 4. Survey diagram reflecting the data about the CPD events participation

The next sector of the survey requested the respondents to give information on the problems and challenges they faced in their professional activity. Only $31,1 \%$ of newly qualified teachers are satisfied with the working conditions; $46,7 \%$ are partially satisfied and $22,2 \%$ expect them to be better and are disappointed with them. When the participants were asked about any fears before or while their first lesson, almost half $(48,9 \%)$ of newly qualified teachers responded that they had had them, some of them $(8,9 \%)$ were just nervous, all the rest had no fears $(42,2 \%)$. The majority commented that the main reasons for fear were:

- maintaining rapport;

- unexpected visitors (other teachers or administration representatives);

- making mistakes;

- keeping discipline; 
- learners could be bored;

- problems with new material understanding;

- forgetting about lesson procedure.

As for the last reason for fear, the next question was about lesson planning problems $44,4 \%$ of those who were interviewed indicated that they didn't have any problems, $46,7 \%$ partially had and $8,9 \%$ needed support because they had problems with lesson planning. Indicating the ways of support in lesson planning they commented that it was possible to get help from experienced colleagues or mentors, tutors, school headmaster or methodologist and former groupmates. They also mentioned some resources they used as the Internet, books for teachers, the literature on methodology.

Besides, the participants were also asked what they considered to be the most perplexing during the first year of work, more than two quarters commented that the hardest was to cope with paperwork $(35,6 \%)$. Other responses to this question included educational process management $(15,6 \%)$; time management and lesson planning (11,1\%); communication with learners $(8,9 \%)$; extracurricular activities and communication with parents $(4,4 \%)$; undisciplined learners and work with learners with special educational needs $(2,2 \%)$; also the $2,2 \%$ of respondents didn't have any difficulties. The responses correlation is shown in Figure 5 (below).

What was/is the most difficult for you during your first year of teaching? You can choose several variants.

45 responses
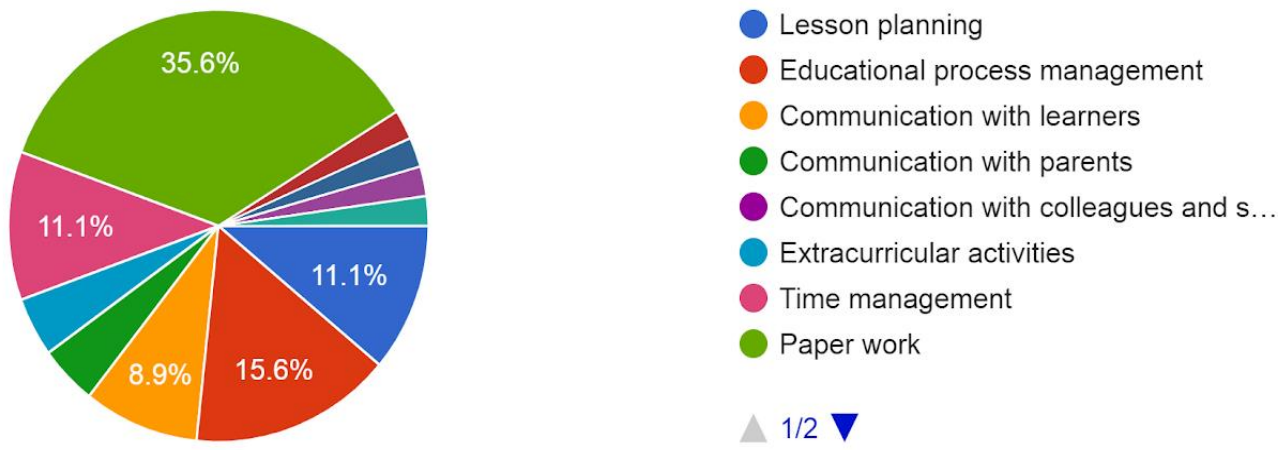

Figure 5. Survey diagram reflecting the data of the main difficulties for newly qualified teachers

Respondents were asked to indicate the ways of coping with the problems of the first-year work among which they reported on spending more time on planning, consulting with experienced colleagues, getting their own experience. The most surprising aspect of the data is in the responses to the question if participants consider that all newly qualified FL teachers have the same problems. Because the data of opposite minds are almost equal: less than half, $40 \%$ of participants agree while $46,7 \%$ of them believe that problems are different, the rest of respondents $(13,3 \%)$ have doubts.

Moreover, respondents were asked to indicate whether they had changed anything in their teaching activity after their first year. More than one-third of the respondents $(35,6 \%)$ reported that they had greatly changed their way of teaching because of getting more experience, nearly the same figure $34,9 \%$ of interviewed hadn't changed their way of teaching much and a minority $(15,6 \%)$ didn't change anything; $13,9 \%$ of respondents answering this question didn't have the experience to share.

The last question in the survey concerned changes which respondents would like to do in order to make the adaptation period in the teaching career easier and more efficient. The list of responses was diverse but there were some items that participants had in common. The majority of those who responded to this question felt that they needed support from an experienced supervisor whom they could ask for help when they need or attend the special course for newly qualified teachers to get appropriate professional help $(31,8)$. About a quarter wanted decreasing paperwork $(15,9 \%)$; more practice while studying at the university $(9,1 \%)$; higher salaries and respect to the teaching profession in society $(9,1 \%)$; emotional development and patience $(4,6 \%)$; academic freedom $(4,6 \%)$; more resources for making lessons interesting $(4,6 \%)$. A small number of those interviewed suggested that newly qualified FL teachers shouldn't be allowed to work with SEN learners because of experience lack; they also elicited the importance of improving formal education for ESL teachers at universities and self-development. 


\section{Discussion}

The present study was designed to determine the challenges, problems, achievements and further prospects of newly qualified FL teachers. The results of this study indicate that newly qualified teachers without working experience face a number of problems and challenges that can influence their choice to stay in this profession.

It was decided that the best method to adopt for this investigation was to conduct a survey using an online questionnaire. The study uses qualitative analysis in order to gain insights into the issues we aimed to research. Data for this study gave us the opportunity to involve teachers from different regions and stages of secondary school. On the one hand, this provides a better picture about serious challenges and problems the newly qualified FL teachers may experience and helps to establish productive achievements because we have received for some questions predictable results. On the other hand, some replies seem surprising and unexpected.

As we worked closely with the programme "New Generation School Teachers" and implemented it in our teacher training course 4 years ago, the biggest interest for us was to confirm the difference in professional readiness between teachers who studied traditional programme and experimental ones. With a few exceptions, our results may emphasise the validity and efficiency of the programme "New Generation School Teachers". And we have got the results which proved the high quality of the New Generation School Teacher Programme as $3 / 4$ of respondents who were participants of the project felt more confident at the very beginning of their work. On the contrary, only $1 / 3$ of the respondents who studied on traditional programmes defined their readiness for professional activity. Without a doubt, considerable insight has been gained with regard to further this programme implementation in the courses of a bigger number of universities and application of this course methodology for other subjects that are suitable for this purpose.

In summary, the results of this study show that participants of the Pre-service English Teacher Training Programme have a higher level of professional readiness for teaching English at school. Further analysis showed that the majority of newly qualified FL teachers take part in different methodological and linguist events for their professional development that increases the evidence in the necessity to provide them with a variety of courses for their further perspectives in career development. On the issue on newly qualified FL teachers' problems, this study found that the respondents consider lack of experience, time for lessons preparations and low salaries as the main drawbacks during their first year of work. One unanticipated finding was defining that the most challenging aspects of the newly qualified FL teachers' work are as follows: a lot of paperwork, inefficient educational process management and time management, lesson planning communication with learners. Together these results provide important insights into the needs of the newly qualified FL teachers. The most significant need is support from an experienced supervisor and the possibility to attend the special course for newly qualified FL teachers that could be helpful during the adaptation period of their career.

The findings of the current study are consistent with those of Vilhelmiina Harju and Hannele Niemi (2016), who indicated that new teachers need support, especially regarding conflict situations and in differentiating their teaching. In addition, when analysing the profiles of eight support-need latent variables, all of the teachers in the different countries viewed supporting students' holistic development as the most important area (Harju \& Niemi, 2016). So, the aspect of steady support may have been an important factor of the professional development and according to the current survey nearly the same results we have got from Ukrainian newly qualified FL teachers.

According to the research "Teacher" and "Reform of education: quality evaluation in the international context", conducted by researches of Ukrainian education researchers association, the majority of teachers are over 30 years, and only $6 \%$ are newly qualified (Shchudlo, Zabolotna \& Lisova, 2018). Such a low percentage is surprising because each year more than 60 universities award diplomas of FLT to their graduates. This study offers indisputable evidence for taking into consideration newly qualified FL teachers' needs urgently in order to construct ways of their support and prevent them from leaving this profession.

A possible explanation for these results may be a traditional formal education which does not meet professional expectations and needs and the lack of adequate support at the initial stage of FL teacher's career. These findings further support the idea of the necessity of the Pre-service English Teacher Training Programme implementing in the university curriculum, the benefits of which in different aspects were indicated in Alan S. Mackenzie's report (Mackenzie, 2019). No doubt, that an innovative methodology course will improve the quality of FL teachers' formal education and supply them with the necessary competencies. However, newly qualified FL teachers even after getting traditional formal education can adapt better if they would have an experienced supervisor. 
Taken together the findings, we recommend universities with pedagogical departments for FL teachers' training to change their curriculum and include the Pre-service English Teacher Training Programme as a Methodology course. Furthermore, it is necessary to create supportive courses for newly qualified FL teachers where they can fill in some professional gaps. One more aspect we consider that can positively influence the FL teachers adaptation is close collaboration between schools (place of their work) and universities to share experience and meet the needs of each other.

This finding has important implications for creating and developing internship for newly qualified FL teachers as one of the stages as an important phase for promoting their careers. It can include different measures which aim is to support and help FL teachers not only to adapt to their profession but also to develop. This is an important issue for future research. In further investigations, it might be possible to work out a plan for a FL teachers' internship or create a list of courses for professional development and define the roles and duties of the newly qualified FL teacher's supervisor.

\section{Limitations}

The most important limitation lies in the fact that the participants were selected randomly and we didn't take into consideration if they work in urban or rural schools. One more limitation of this study is that respondents were indicated only from western, eastern and central parts of Ukraine. However, the obtained results include large geographical territory and can reflect the data from the whole country.

\section{Conclusions}

To sum up, this study has shown that the effectiveness of the New Generation School Teachers Project revealed different data between its participants and traditional training former students. This is the main reason for conducting the survey that helped us find replies to our research questions. Firstly, we intended to define the problems which newly qualified FL teachers face at the very beginning of their career and consider the most difficult, important and needed solution. Surprisingly, the low salary problem is not the most vital for the respondents as we have expected. The biggest problems for newly qualified FL teachers are paperwork and poor time management. Moreover, it is worth mentioning that affective filters also influenced negatively at the beginning of the teaching activity.

Another important finding reinforces the issue of measures that the newly qualified FL teachers need is to considerably have the support during their adaptation in profession. Overall, the results of the survey indicate that newly qualified teachers need a mentor who can support and help to choose appropriate materials and tools for classes, ready to share experience and answer the questions on how to prepare a wellplanned lesson, can analyse the lesson to find drawbacks and give efficient pieces of advice. The obtained comprehensive results of this survey prove that traditional training course graduates stress a need in length of school practice, considering it the important opportunity to get experience.

Our work has led us to conclude that these findings have important implications for developing cooperation with universities that can provide different programmes for continuing professional development and include the issues that newly qualified FL teachers consider the most essential in the relevant programmes. In further research, the use of this data as participation in different educational events for professional development could be a means of setting new ties and cooperation between newly qualified and experienced teachers not only at schools but at universities as well.

\section{References:}

Adendorff, M., Mason, M., Modiba, M., Faragher, L., \& Kunene, Z. (2010). Being a Teacher: Professional Challenges and Choices. SAIDE Teacher Education. South African Institute for Distance Education (SAIDE), Braamfontein, South Africa.

Bevz, O., Gembaruk, A., Honcharova, O., Zabolotna, O., Zmiievska, O., Kalinina, L., Kamynin, I., Konovalenko, T., Romanyshyn, I., Samoiliukevych, I., Taran, O., Tuchyna, N., \& Hudyk, K. (2020). Typova prohrama "Metodyka navchannia anhliiskoii movy" Osvitnii stupin bakalavra [Core Curriculum English Language Teaching Methodology. Bachelor's Level]. Ivano-Frankivsk: NAIR.

Biletska, I. O. (2014). Inshomovna osvita SShA: Polikulturni zasady [Foreign language education of the USA: multicultural bases]. The Scientific Issues of Ternopil Volodymyr Hnatiuk National Pedagogical University. Series: Pedagogy, 1, $168-174$. http://nzp.tnpu.edu.ua/article/view/65358

Bondaruk, Ya. (2018). Innovatsiini zminy v orhanizatsiii systemy pidvyshchennia kvalifikatsiii vchyteliv u SShA [Innovative changes in the organisation of the teacher development in the USA]. Innovations in modern education: Ukrainian and world context. Proceedings of the of the Scientific and Practical Conference (pp.45-50). Uman, Ukraine.https://dspace.udpu.edu.ua/jspui/handle/6789/9810

Conceptual principles of state policy on the English language development in the field of higher education: Project (2019). https://mon.gov.ua/ua/news/mon-stvorilo-koncepciyu-rozvitku-anglijskoyi-v-universitetah-u-dodatku-riven-v1obovyazkova-umova-vstupu-v2-vipusku-vikladannya-profilnih-disciplin-inozemnoyu-ta-movniskriningi?fbclid=IwAR2ICPzauy6r5JKmZYAPMKglPn9TXxjqaekymfOGHYmmJuXkNoH1SLgQnGo. 
Darling-Hammond, L., \& Baratz-Snowden, J. (2007). A Good Teacher in Every Classroom: Preparing the Highly Qualified Teachers Our Children Deserve. Educational Horizons.

England, L. (2019). Teacher Education. In L. England (Ed.), Tesol Career Path Development. Creating Professional Success (pp. $30-$ 41). Routledge. http://doi.org/10.4324/9780429458484-3

Fransson, G., \& Gustafsson, C. (2008). Newly qualified teachers in Northern Europe - Comparative perspectives on promoting professional development teacher education: Research publication 4. Gävle, Sweden. http://www.hig.se/download/18.2ab4fe5a1394206308480001691/1353630704291/NQTNE_publication_chapter+1.pdf

Harju, V., Niemi, H. (2016). Newly Qualified Teachers' Needs of Support for Professional Competences in Four European Countries: Finland, the United Kingdom, Portugal, and Belgium. CEPS Journal, 6(3), 77-100. http://www.cepsj.si/pdfs/cepsj_6_3/pp_77-100_Harju_Niemi.pdf.

He, Y., \& Cooper, J. (2011). Struggles and strategies in teaching: Voices of five novice secondary teachers. Teacher Education Quarterly, 97-116. http://web.ebscohost.com/ehost/pdfviewer/pdfviewer?vid=4\&hid=24\&sid=29269770-e458-4e9f-91acc68c0bd218cf\%40sessionmgr15

Høigaard, R., Giske, R., \& Sundsli, K. (2012). Newly qualified teachers' work engagement and teacher efficacy influences on job satisfaction, burnout, and the intention to quit. European Journal of Teacher Education, 35(3), 347-357. https://doi.org/10.1080/02619768.2011.633993

Hryniuk, S. (2015). Standards for foreign language teaching and learning in the 21st century. Scientific Bulletin of the International Humanities University. Series: Philology, 14, 136-139.

Kearney, E. M., (2013). On Becoming A Teacher. Sense Publisher, the Netherlands.

Knight, P., Tait, J., \& Yorke, M. (2006). The professional learning of teachers in higher education. Studies in Higher Education, 31(3), 319-339. https://doi.org/10.1080/03075070600680786

Koliada, N. M., \& Kolisnichenko, A. I. (2020). Otsiniuvannia yakosti pidhotovky vchyteliv inozemnyh mov: pohliad studentiv na suchasnu pedahohichnu osvitu [Quality Assessment of the FL Teachers' Training: a Students' View on Contemporary Pedagogical Education]. Problemy pidhotovky suchasnoho vchytelia, 21, 83-90. https://doi.org/10.31499/23074914.21.2020.205458

Komar, O. (2017). English language teaching and teachers training at the University of Porto and Pavlo Tychyna Uman State Pedagogical University: comparative analysis. Studies in Comparative Education, 1(31), $48-57$. https://doi.org/10.31499/2306-5532.1(31).2017.112949

Livingston, K. (2014). Teacher educators: Hidden professionals? European Journal of Education, 49(2), 181-232. https://doi.org/10.1111/ejed.12074.

Mackenzie, A. S. (2019). Evaluation of PRESETT Ukraine: New Generation School Teacher Project. Retrieved 19 October 2020 from https://www.britishcouncil.org.ua/sites/default/files/evaluation_report_of_presett_project.pdf.

Protsko, Ye. (2015). English Teacher Training in Belgium and Ukraine: the Comparative Analysis. The Advansed Science Journal, 3 , 55-58. http://doi:10.15550/ASJ.2015.03.055

Ram, A. (2010). Research Methodology. New Delhi: Rawat Publication.

Shchudlo, S., Zabolotna, O., \& Lisova, T. (2018). Ukrainian Teachers and Learning Environment The results of All-Ukrainian Monitoring Survey of Secondary School Teachers and Principals (by the TALIS methodology). Executive report. Drohobych: Trek LTD.

Sunde, E., \& Ulvik, M. (2014). School leaders' views on mentoring and newly qualified teachers' needs. Education Inquiry, 5 , 285-299. http://www.educationinquiry.net/index.php/edui/article/viewFile/23923/33671.

Tican, C., Deniz, S. (2019). Pre-Service Teachers' Opinions about the Use of 21st Century Learner and 21st Century Teacher Skills. European Journal of Educational Research, 8(1), 181-197. doi: 10.12973/eu-jer.8.1.181

Trynus, O. (2017). The Problem of Recognition of the Young Teacher Status in Ukraine. Science Rise: Pedagogical Education, 1, 15-19. https://doi:10.15587/2519-4984.2017.91294.

Zabolotna, O. A. (2014). Innovatsiini tehnolohiii vykladannia inozemnyh mov v umovah internatsionalizatsiii osvitnioho prostoru [Innovative technologies of foreign languages teaching in the conditions of educational area internationalization]. Studies in Comparative Education, 4(22), 117-122. https://doi.org/10.31499/2306-5532.4.2014.50683 
Appendix

List of questions for online survey

1. Your name

2. Your gender

3. Work experience

4. What educational institution do you represent? (Place of work).

5. What methodology course did you study at university?

6. Point out your level of professional readiness for teaching English at school after getting your Bachelor's or Master's Degree at university?

7. Are you a member of any professional organisations?

8. If you answered "yes" to the previous question, mention which ones.

9. Do you participate in seminars, webinars, workshops, conferences? If yes, tick events.

10. Are they useful for your CPD (continuing professional development)?

11. What age range of learners do you work with?

12. Do your working conditions meet your professional needs?

13. Did you have any fear before the first lesson? What was it about?

14. Did/do you have problems with planning your lessons during your first year of work?

15. Who or what did/do you need to support you during your first year of work?

16. What was/is the most difficult for you during your first year of teaching? You can choose several variants.

17. How did/do you cope with it?

18. Do you think that all "young teachers" have the same problems during their first years of work or they are different? Why?

19. Has your way of teaching changed after the first year of work? If yes, how?

20. What would you change in order to make the first year of teaching less stressful and more efficient for new teachers? 